\title{
Simulasi Kebijakan Penambahan Areal Tanam dan Peningkatan Produktivitas dalam Mendukung Tercapainya Swasembada Jagung
}

\author{
The Simulation of Additional Plant Areas and Productivity Policy on Corn Self Sufficiency \\ Parama Tirta Wulandari Wening Kusuma ${ }^{{ }^{*}}$, Didik Junaedi Rachbini ${ }^{2}$ \\ ${ }^{1}$ Biro Perencanaan dan Keuangan, Lembaga Ilmu Pengetahuan Indonesia, Jl. Jend. Gatot Subroto, No. 10, \\ Jakarta, Indonesia \\ 2Magister Perencanaan Ekonomi dan Kebijakan Pembangunan, Fakultas Ekonomi dan Bisnis, \\ Universitas Indonesia, Gedung MPKP FEB UI, Kampus UI Salemba, Jl. Salemba Raya No. 4, Senen, \\ Jakarta Pusat 10430, Indonesia \\ *Email: paramatirtawwk@gmail.com
}

Tanggal submisi: 27 Maret 2019; Tanggal penerimaan: 31 Mei 2019

\begin{abstract}
ABSTRAK
Jagung merupakan salah satu komoditi utama yang diharapkan mampu mencapai swasembada hingga akhir RPJMN 2019. Swasembada jagung bertujuan untuk pemenuhan dari produksi dalam negeri dan tidak ada lagi kebijakan impor. Pemerintah melalui Kementan menerbitkan kebijakan swasembada jagung dengan ekstensifikasi dan intensifikasi, dengan skenario Penambahan Areal Tanam (PAT) seluas 3 juta Ha dan peningkatan produktivitas 53,13 Ku/Ha. Penelitian ini bertujuan untuk: (1) mengukur ketercapaian swasembada jagung nasional dengan membangun model sistem dinamis ketersedian jagung nasional sebelum dan sesudah ada kebijakan swasembada; (2) menyusun kebijakan alternatif agar swasembada jagung dapat tercapai. Penelitian ini menggunakan pendekatan sistem dinamik dengan menggunakan data sekunder dari Kementan dan BPS, menentukan hipotesis dinamis dan model dari siste, membuat causal loop diagram dan menghitung stock flow diagram, serta memvalidasi dan verifikasi model. Hasil validasi dan verifikasi menggambarkan bahwa model yang dibuat sesuai dengan kondisi aktual yang ada. Selanjutnya simulasi menunjukan bahwa swasembada jagung dapat tercapai secara berkelanjutan hingga tahun 2019 melalui kebijakan peningkatan indeks pertanaman, dan skenario ekstensifikasi (PAT) realistis, ekstensifikasi optimis dan perpaduan antara kebijakan ektensifikasi realistis dan intensifikasi.
\end{abstract}

Kata kunci: Jagung; PAT; produktivitas; swasembada; simulasi; sistem dinamika

\begin{abstract}
Corn is one of five main commodities that is expected to achieve self-sufficiency at the end of RPJMN 2019. However, the gap between supply and demand capacities was still quite large, so that imports are still conducted. The government through the Ministry of Agriculture issued a self-sufficiency policy through extensification and intensification, with the scenario of Planting Areas increase (PAT) of up to 3 million $\mathrm{Ha}$, and productivity increase of up to $53.18 \mathrm{Ku} / \mathrm{Ha}$. This study aims to: (1) measure the achievement of national corn self-sufficiency by establishing a model of national corn availability dynamic system before and after the self-sufficiency policy; (2) develop some policy alternatives for corn self-sufficiency. This article used a dynamic system approach based on secondary data from the Ministry of Agriculture and BPS, determined dynamic hypotheses and systems models,
\end{abstract}


made causal loop diagrams, calculated stock flow diagrams, and validated and verified the models. The results of validation and verification illustrated that the model was made in accordance with the actual conditions that exist. The simulation results showed that increasing the cropping index can continuously achieve maize self-sufficiency until 2019, as well as the scenario of realistic, optimistic extensification (PAT) and the combination of realistic and intensification.

Keywords: Corn; PAT; productivity; self-sufficiency; simulation; system dynamic

\section{PENDAHULUAN}

Fokus komoditas strategis pertanian yang dikembangkan dalam RPJMN 2015-2019 adalah pada pengembangan lima bahan pangan pokok strategis yaitu: padi, jagung, kedelai, gula (tebu) dan daging sapi-kerbau. Dalam Renstra Kementerian Pertanian (Kementan) 2015-2019 peran jagung sebagai pangan pokok karbohidrat utama memiliki dua fungsi yaitu sebagai bahan makanan pokok nasional dan bahan makanan pokok lokal. Selain makanan pokok sumber karbohidrat, jagung juga banyak digunakan sebagai bahan baku industri, seperti minyak goreng (corn oil), gula rendah kalori, tepung jagung (maizena) sebagian kecil mulai dipergunakan sebgai bahan baku bahan bakar ramah lingkungan (bioetanol), dan sebaagai komponen utama pakan terutama pakan ternak lokal dan pakan pabrikan. Lima (5) besar wilayah penghasil jagung terbesar di Indonesia adalah Jawa Timur; Jawa Tengah; Sulawesi Selatan; Sumatera Utara; dan Lampung (BPS, 2017).

Dalam Outlook Jagung (2016), Kebutuhan jagung meningkat setiap tahunnya mengikuti perkembangan industri peternakan. Peningkatan kebutuhan pakan ini didorong dengan adanya pergeseran pola makanan ke pangan yang berasal dari produk ternak (Swastika, 2005).

Dari hasil olah data Produksi Jagung Kementan (2016) selisih antara kebutuhan dan ketersedian jagung dari tahun 2009-2013 terjadi kecenderungan penurunan persentase pemenuhan kebutuhan jagung melalui produksi domestic. Tahun 2009 sebesar 98\%; 2010 turun menjadi 91\%; dan tahun 2011 merupakan yang terendah dimana produksi domestik hanya mampu menutup $84 \%$ kebutuhan jagung nasional; kemudian 2012 terjadi peningkatan ke 92\%; dan 2013 turun kembali menjadi $89 \%$. Ketersedian jagung yang fluktuatif mendorong pemerintah untuk melakukan impor, tertinggi pada tahun 2011 yaitu sebesar 3,3 juta ton untuk menutup kekurangan hasil produksi di tahun tersebut.

Membangun swasembada pangan menjadi sangat penting dan strategis sebagai upaya penyediaan pangan yang dilakukan dengan produksi berbasis sumber daya lokal (kemampuan produksi domestik dalam memenuhi kebutuhan hingga kepada tingkat perseorangan). Pemerintah melakukan peningkatan produksi jagung untuk memenuhi semua kebutuhan pangan dan pakan dengan melakukan intensifikasi dan ekstensifikasi secara bersamaan. Swasembada sendiri memiliki beberapa definisi menurut, Jusuf Kalla dalam Falianty (2012), swasembada tak bisa diartikan kaku atau disamakan dengan zero import. Mulatsih (2012) dan Suryana (2008), dalam tulisannya menyatakan bahwa definisi swasembada yaitu 90\% kebutuhan dipenuhi dari produksi lokal dan 10\% impor. Kemudian Purwantini (2013), menyatakan bahwa swasembada pangan adalah kemampuan mengadakan sendiri kebutuhan pangan dan harus mengarah kepada kemandirian pangan. Sedangkan definisi swasembada pangan yang dirumuskan Kementan adalah pemenuhan kebutuhan pangan oleh $100 \%$ produksi domestik dan zero import.

Pada Pedoman Pelaksanaan Kegiatan (Pedlak) Jagung Direktorat Jenderal Tanaman Pangan 2017, mencantumkan bahwa pada tahun 2017 pemerintah akan melakukan kebijakan ektensifikasi dan intensifikasi. Kebijakan ektensifikasi melalui peningkatan luas (areal) tanam (PAT) seluas 3 juta Ha. Dimana 2 juta Ha menjadi tanggung jawab Direktorat Jenderal Tanaman Pangan dan 1 juta ha menjadi tanggung jawab Direktorat Jenderal Perkebunan. Sehingga di harapkan pada akhir tahun 2017 luas areal lahan yang siap tanam jagung mencapai 6,1 juta Ha. Kebijakan intensifikasi melalui peningkatan produktivitas jagung dengan cara mengoptimalkan lahan yang sudah ada dan berfokus kepada pengelolaan tanah, penggunaan benih bermutu untuk meningkatkan mutu serta kualitas produksi jagung, penanaman, pemupukan yang tepat, pemanenan dan kegiatan selama pasca panen, sasaran produktivitas jagung secara nasional di targetkan mencapai 53,13 ku/Ha di tahun 2017.

Simulasi dan analisis dari skenario kebijakan yang diambil pemerintah diHerlukan untuk melihat dan mengevaluasi apakah kebijakan kebijakan tersebut akan mendukung dalam peningkatan produksi komoditi jagung dan mencapai swasembada jagung di akhir RPJMN 2014-2019. Seperti yang ditargetakan bahwa sampai dengan 2019 kebutuhan dapat dipenuhi dari 
produksi dari dalam negeri (zero import). Berdasarkan uraian tersebut maka penelitian ini bertujuan untuk menganalisa pengaruh kebijakan ekstensifikasi atau PAT jagung terhadap tercapainya swasembada jagung nasional, menganalisa pengaruh kebijakan intensifikasi melalui peningkatan produktivitas jagung terhadap tercapainya swasembada jagung nasional, dan melalui penerapan dua kebijakan tersebut, apakah Indonesia mampu mencapai swasembada jagung di akhir RPJMN III atau tahun 2019.

\section{METODE PENELITIAN}

Penelitian ini menggunakan pendekatan sistem dinamik dengan menggunakan data sekunder dari Kementan dan Badan Pusat Statistik. Metodologi ini dititikberatkan pada pengambilan kebijakan dan bagaimana kebijakan tersebut menentukan tingkah laku masalah-masalah yang dapat dimodelkan oleh sistem secara dinamik (Richardson dan Pugh, 1986 dalam Somantri, 2007). Ketika menggunakan sistem dinamik dalam analisis maka akan ditemukan beberapa instrumen dasar untuk membangun model maupun mengoperasikan model. Metode pendekatan ini digunakan untuk merancang bangun model kebijakan PAT dan produktivitas dalam mendukung ketercapaian swasembada jagung dengan berbagai rekayasa skenario (pesimis, oprimis, realistis dan mix antar kebijakan) yang dapat dilakukan dengan menggunakan sistem dinamik.

Beberapa penelitian terdahulu yang membahas mengenai swasembada pangan untuk komoditas padi, gula, beras, coklat serta menggunakan metode sistem dinamik yang dijadikan referensi diantaranya adalah Mahbubi, (2015); Hasibuan dkk., (2012); Sofyang dkk., (2012); Dharmayanti dkk., (2013); Yunitasari, (2015); Hasan dkk., (2015); Wibowo (2016); Aminudin (2014); Harmini dkk., (2011); Zakaria (2011); Tastra, dkk. (2012); Banctacut dkk., (2015); dan Ustrina, (2015).

Dalam pendekatan sistem secara umum tahapan analisis diantaranya adalah: perumusan masalah, formulasi hipotesis dinamis, formulasi model, pengujian, dan menyusun skenario untuk dievaluasi (Harmini dkk., 2011; Mahbubi, 2013; Wibowo, 2016; Sterman, 2000). Kelebihan simulasi dengan menggunakan metode sistem dinamis utamanya adalah dapat menggambarkan proses, perilaku, dan kompleksitas dalam sistem yang bersifat uncertainty dan sesuai dengan kondisi actual (setelah melalui proses validasi dan verifikasi) dibanding metode peramalan atau simulasi lainnya, sedangkan kekurangannya adalah jika suatu system actual semakin kompleks maka dibutuhkan variable yang cukup banyak dan waktu dalam penyusunan modelnya.

Formulasi hipotesis digunakan untuk menjelaskan keadaan aktual sebelum adanya formulasi tertentu dan tujuan yang akan dicapai jika dilakukan perubahan kebijakan. Penelitian ini mencoba mengubah skenario, khususnya pada kebijakan PAT menjadi skenario pesimis, realistis dan optimis terhadap pencapaian produksi jagung. Dari Gambar 1 menunjukkan bahwa neraca jagung dipengaruhi oleh besarnya kebutuhan atau permintaan jagung dan produksi jagung dalam negeri. Semakin besar produksi jagung maka neraca

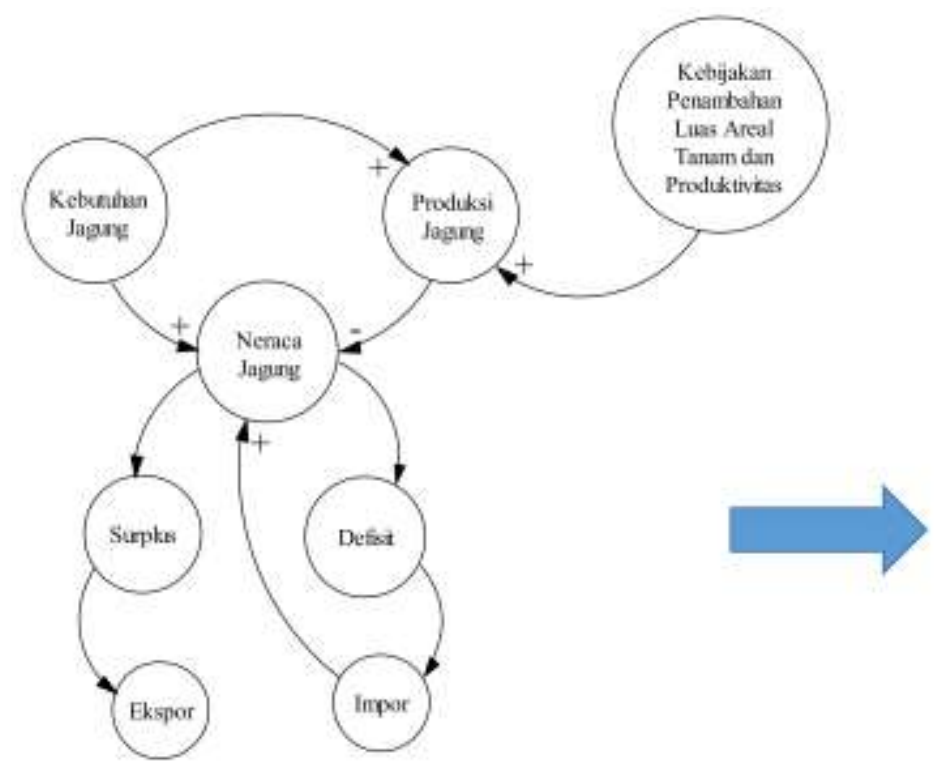

Gambar 1. Hipotesis dinamis

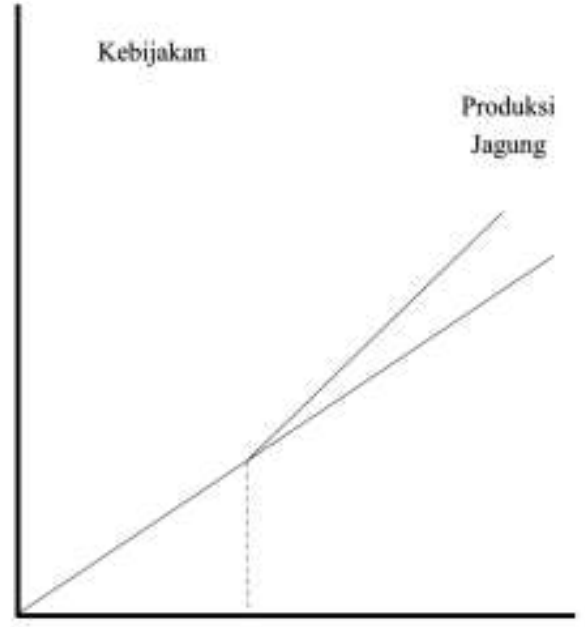

2017 


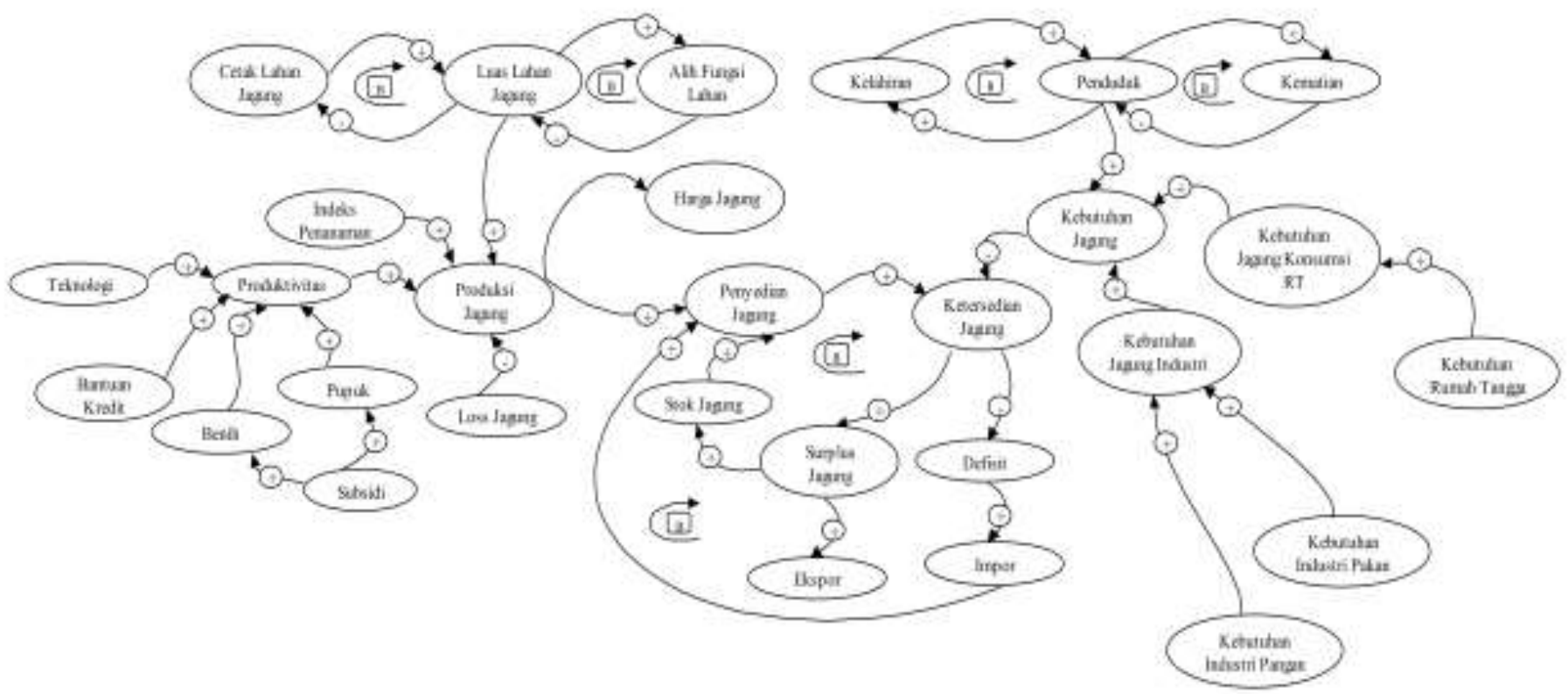

Gambar 2. Causal loop diagram

jagung akan semakin baik (swasembada dan surplus), sedangkan apabila produksi sedikit maka neraca akan defisit.

Dalam penelitian ini identifikasi Sistem (Causal Loop Diagram) dibagi menjadi 8 subsistem, dengan 3 subsistem utama yaitu subsistem produksi jagung, subsistem ekspor impor jagung, dan subsistem kebutuhan jagung. Subsistem lainnya adalah lahan jagung, luas panen, produksi jagung, neraca jagung, ekspor impor, dan penduduk. Model ini dibuat berdasarkan identifikasi permasalahan yang dituangkan ke dalam diagram sebab akibat (causal loop) seperti pada Gambar 2.

Jika terjadi hubungan umpan balik antar variabel dalam diagram sebab akibat maka keterkaitan tersebut disebut sebagai suatu (feedback loop). Selanjutnya pengembangan model dinamis diintegrasikan dengan analisis statistik guna mempelajari hubungan antar variable yang saling terkait melalui pembuatan stock flow diagram pada Gambar 3.

Validasi Model diperlukan guna memastikan bahwa model yang telah berhasil dibangun dapat merepresentasikan kondisi aktual. Model dinyatakan valid saat deviasi berada kurang dari $10 \%$. Absolute Mean Error (AME) adalah penyimpangan (selisih) antara nilai rata-rata (mean) hasil simulasi terhadap nilai aktual. Absolute Variation Error (AVE) adalah penyimpangan nilai variasi (variance) simulasi terhadap aktual. Sedangkan verifikasi model dengan melihat kecenderungan atau pola hasil simulasi terhadap kondisi aktual.
Simulasi hanya dilakukan sampai dengan tahun 2019 untuk melihat apakah target swasembada jagung dapat dicapai dan memenuhi agenda untuk zero import. Somantri (2007) dan Axella (2012) menyatakan bahwa skenario dibuat untuk melihat kemampuan dan kehandalan suatu objek terhadap pencapaian tujuan akhir, skenario biasanya berupa kebijakan yang bersifat struktur, misal melalui perluasan ataupun peningkatan produksi. Model yang telah dibentuk dan sah setelah validasi kemudian disimulasikann di mana tahun 2009 merupakan titik awal simulasi $(\mathrm{t}=0)$, skenario kebijakan diterapkan mulai tahun 2017. Karena kebijakan ekstensifikasi dan intensifikasi seperti yang diuraikan diatas baru diterapkan di tahun 2017.

Tabel 2. Skenario kebijakan

\begin{tabular}{lll}
\hline No. & \multicolumn{1}{c}{ Skenario Kebijakan } & \\
\hline 1. & Skenario ekstensifikasi dengan PAT & \\
& Skenario pesimis & $\begin{array}{l}\text { PAT dua kali fraksi tahun } \\
\text { sebelumnya, 0,732/tahun }\end{array}$ \\
& PAT 1 juta Ha di akhir 2017 \\
& Skenario realistis & PAT 2 juta Ha di akhir 2017 \\
2. $\begin{array}{l}\text { Skenario intensifikasi dengan } \\
\text { peningkatan produktivitas 53,13 } \\
\text { ku/Ha }\end{array}$ & \\
3. $\begin{array}{l}\text { Skenario ekstensifikasi realistis dan } \\
\text { intensifikasi }\end{array}$ & \\
\hline
\end{tabular}




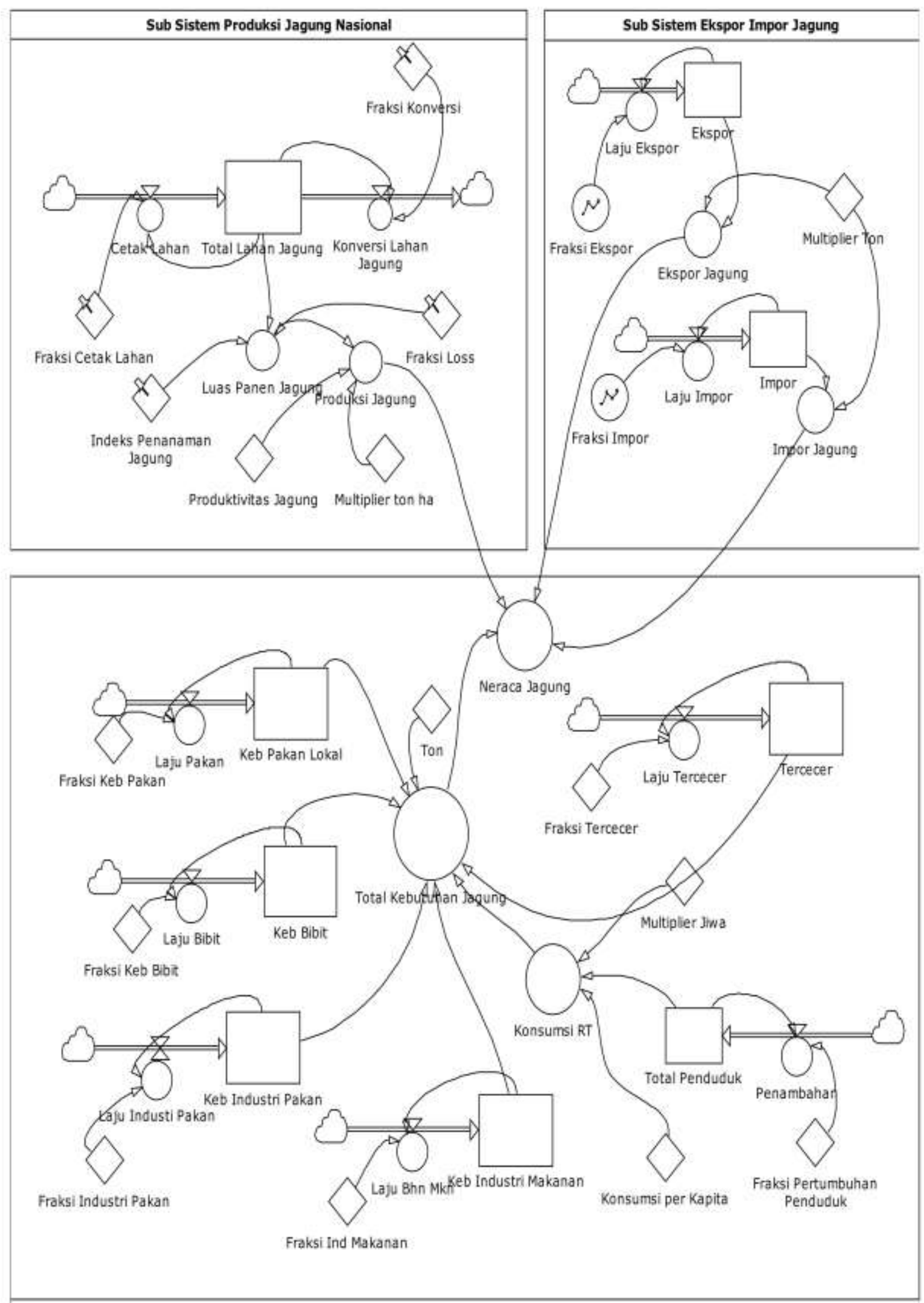

Sub Sistem Kebutuhan Jagung Nasional

Gambar 3. Stock flow diagram 


\section{HASIL DAN PEMBAHASAN}

Dari Stock Flow Diagram dapat dilihat bahwa permodelan sistem jagung nasional dibagi menjadi tiga sub sistem pendukung yaitu: (a) sub sistem produksi jagung; (b) sub sistem ekspor impor; dan (c) sub sistem kebutuhan jagung nasional. Kemudian dari ketiga sub sistem akan dibagi lagi menjadi tujuh permodelan yaitu: luas lahan tanam; luas panen; produksi jagung; penduduk; kebutuhan jagung; ekspor; dan impor. Pada Tabel 3 dapat dilihat hasil perhitungan AME dan AVE setiap model, dimana nilai AME dan AVE ketujuh model berada jauh di bawah $10 \%$ sehingga dapat disimpulkan bahwa model yang dibuat valid, serta terverifikasi dengan baik dan tepat.

Tabel 3. Hasil verifikasi dan validasi model

\begin{tabular}{lccl}
\hline \multicolumn{1}{c}{ Model } & AME & AVE & Hasil \\
\hline Luas lahan tanam & $2,16 \%$ & $1,01 \%$ & Valid \\
Luas panen & $1,58 \%$ & $1,20 \%$ & Valid \\
Produksi jagung & $3,05 \%$ & $3,56 \%$ & Valid \\
Penduduk & $0,11 \%$ & $0,07 \%$ & Valid \\
Kebutuhan jagung & $0,14 \%$ & $0,29 \%$ & Valid \\
Ekspor & $0,40 \%$ & $0,40 \%$ & Valid \\
Impor & $0,20 \%$ & $0,60 \%$ & Valid \\
\hline
\end{tabular}

\section{Kondisi Awal Sistem Dinamis Jagung}

Terjadi gap atau defisit yang cukup besar terhadap tingkat permintaan jagung, sehingga salah satu cara yang "mungkin" akan dilakukan oleh pemerintah adalah dengan kembali memberlakukan impor jagung. Tujuan swasembada jagung tentu saja
Tabel 4. Kondisi neraca jagung tanpa kebijakan

\begin{tabular}{cccc}
\hline Tahun & Produksi (ton) & Kebutuhan (ton) & Neraca jagung \\
\hline 2016 & 19.186 .461 & 23.629 .228 & $(4.442 .767)$ \\
2017 & 18.738 .427 & 24.295 .635 & $(5.557 .208)$ \\
2018 & 18.329 .929 & 24.983 .347 & $(6.653 .418)$ \\
2019 & 17.930 .337 & 25.693 .370 & $(7.763 .033)$ \\
\hline
\end{tabular}

tidak akan tercapai apabila pemerintah tidak melalukan berbagai skenario kebijakan yang dapat meningkatkan produksi jagung.

Pada Gambar 4 dapat dilihat bahwa terjadi "gap" atau selisih kekurangan produksi untuk pemenuhan kebutuhan jagung. Besarnya kekurangan pemenuhan jagung dapat dilihat pada Tabel 4, dimana neraca jagung (Kebutuhan Jagung - Produksi jagung) selalu defisit, dan cenderung selalu naik sampai tahun 2019.

\section{Simulasi Kebijakan}

\section{Kebijakan ekstensifikasi optimis}

Dari hasil simulasi untuk scenario kebijakan ektensifikasi optimis dapat dilihat pada Gambar 5 bahwa produksi di tahun 2017-2018 mampu memenuhi kebutuhan nasional. Sehingga ada kelebihan stock produksi atau surplus jagung yang dapat di jadikan ekspor ke negara lain. Meskipun ditahun 2019 kembali terjadi defisit atau tidak terpenuhi permintaan jagung nasional, dengan nilai yang tidak terlalu banyak, dan dapat di tutupi dengan melakukan atau mengambil stock tahun sebelumnya. Pada Tabel 5 dapat dilihat bahwa di tahun 2019 akan terjadi defisit pada neraca jagung sebesar 139,616 ton jika melakukan skenario ini.

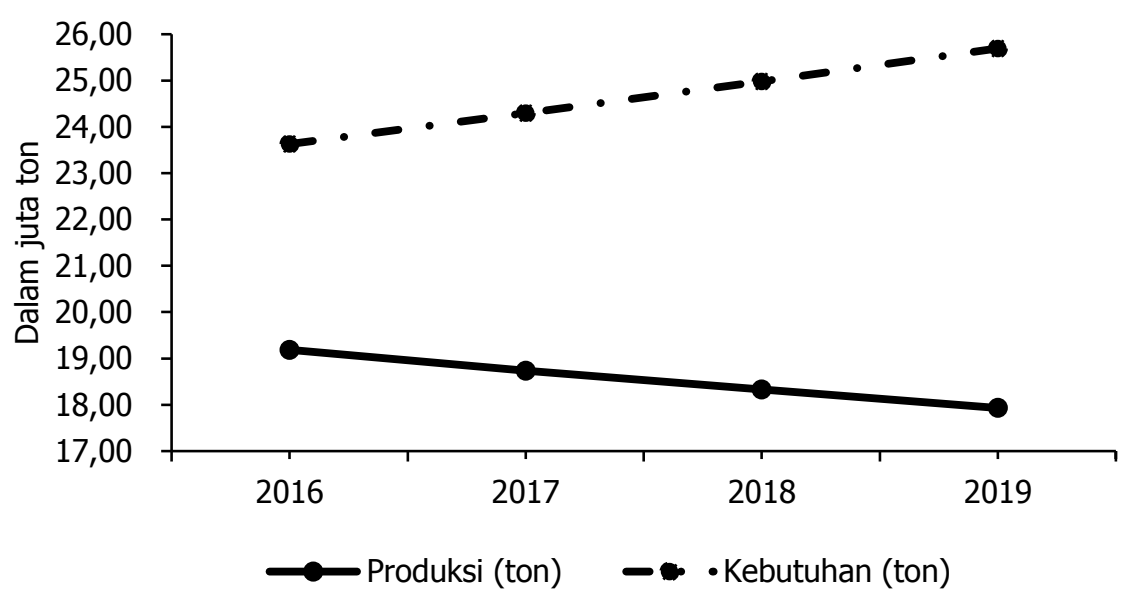

Gambar 4. Proyeksi produksi dan kebutuhan kondisi awal (tanpa kebijakan) 


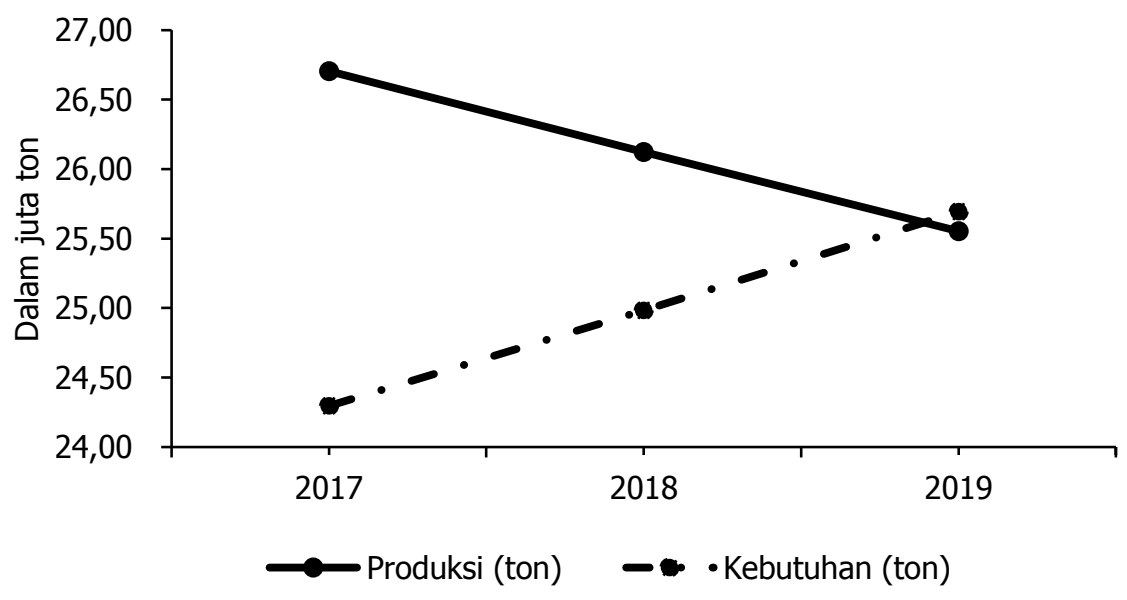

Gambar 5. Grafik simulasi ekstensifikasi optimis

Tabel 5. Hasil simulasi ekstensifikasi optimis

\begin{tabular}{ccccc}
\hline Tahun & Produksi (ton) & Kebutuhan (ton) & Neraca & Kesimpulan \\
\hline 2017 & 26.705 .419 & 24.295 .635 & 2.409 .784 & Surplus \\
2018 & 26.123 .241 & 24.983 .347 & 1.139 .894 & Surplus \\
\hline 2019 & 25.553 .754 & 25.693 .370 & $(139.616)$ & Defisit \\
\hline
\end{tabular}

\section{Kebijakan ekstensifikasi pesimis}

Dari hasil simulasi untuk skenario kebijakan ektensifikasi pesimis, dapat dilihat pada Gambar 6 , terjadi gap atau selisih yang cukup besar antara produksi terhadap pemenuhan kebutuhan jagung. Neraca jagung pada Tabel 6 memperlihatkan bahwa pada tahun 2017-2019 kekurangan kebutuhan jagung atau defisit mencapai 4-5 juta/tahun-nya, dikarenakan penambahan luas lahan tanam hanya sekitar 56.331 Ha. Jika dibandingkan dengan kondisi eksisting (tanpa kebijakan), defisit permintaan jagung menurun, namun jarak atau selisih pemenuhan masih sangat besar.

Tabel 6. Hasil simulasi ekstensifikasi pesimis

\begin{tabular}{ccccc}
\hline Tahun & Produksi (ton) & Kebutuhan (ton) & Neraca & Kesimpulan \\
\hline 2017 & $19,439.537$ & 24.295 .635 & $(4.856 .098)$ & Defisit \\
2018 & 19.727 .243 & 24.983 .347 & $(5.256 .104)$ & Defisit \\
2019 & 20.019 .206 & 25.693 .370 & $(5.674 .164)$ & Defisit \\
\hline
\end{tabular}

\section{Kebijakan ekstensifikasi realistis}

Dari hasil simulasi untuk skenario kebijakan ektensifikasi realistis, pada grafik Gambar 7 dapat dilihat bahwa produksi di tahun 2017 mampu mendekati total kebutuhan atau konsumsi jagung nasional, meskipun ditahun 2018-2019 kembali terjadi defisit atau tidak terpenuhi permintaan jagung nasional. Dari Tabel 7 nilai kekurangan atau selisih produksi jagung terhadap kebutuhan pada skenario realistis semakin berkurang

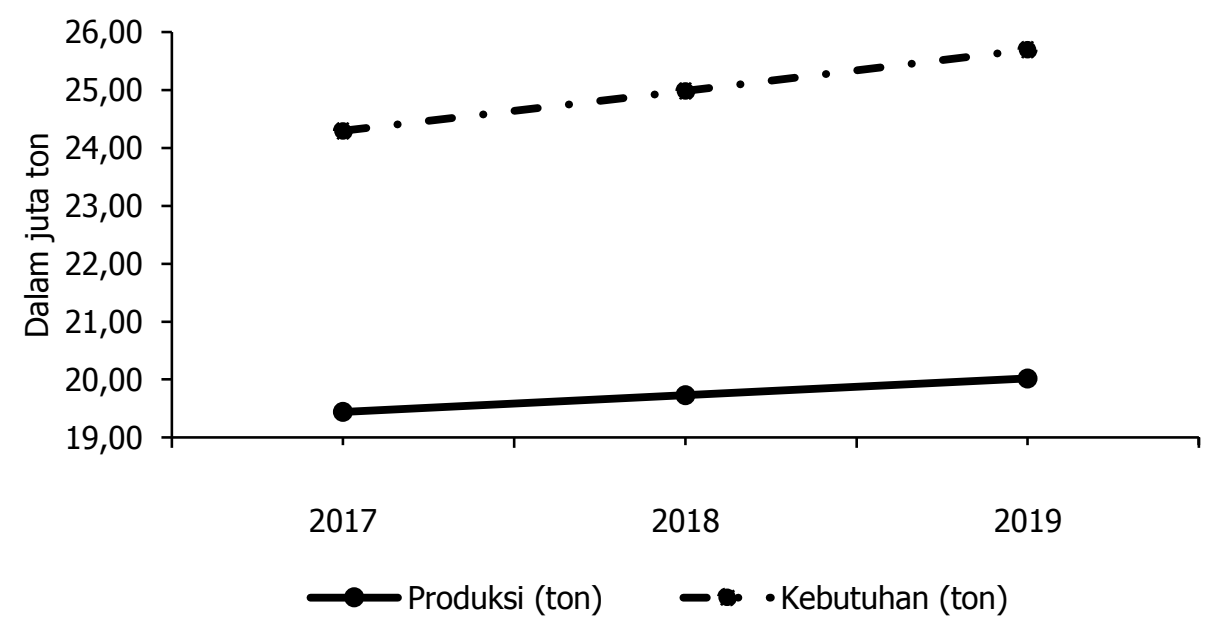

Gambar 6. Grafik simulasi ekstensifikasi pesimis 


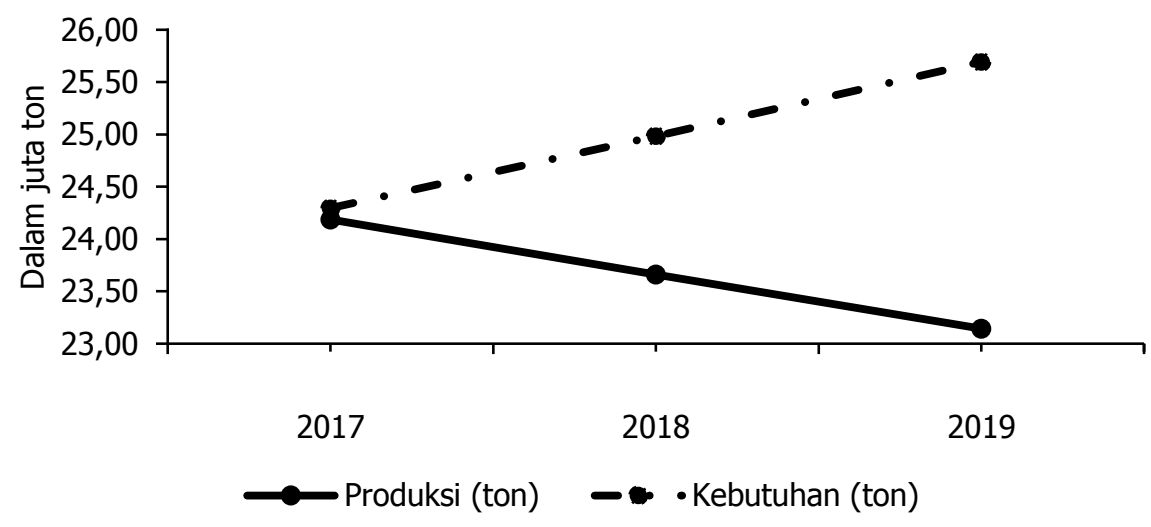

Gambar 7. Grafik simulasi ekstensifikasi realistis

dibanding skenario pesimis, meskipun masih defisit namun hanya sekitar 2,5 juta ton di tahun 2019.

Tabel 7. Hasil simulasi ekstensifikasi realistis

\begin{tabular}{ccccc}
\hline Tahun & Produksi (ton) & Kebutuhan (ton) & Defisit & Kesimpulan \\
\hline 2017 & 24.186 .401 & 24.295 .635 & $(109.234)$ & Defisit \\
2018 & 23.659 .138 & 24.983 .347 & $(1.324 .209)$ & Defisit \\
2019 & 23.143 .369 & 25.693 .370 & $(2.550 .001)$ & Defisit \\
\hline
\end{tabular}

\section{Kebijakan intensifikasi}

Gambar 8 memperlihatkan hasil simulasi untuk skenario kebijakan intensifikasi, dimana masih terjadi gap atau tidak terpenuhinya kebutuhan jagung melalui produksi domestik meskipun peningkatan produktivitas jagung dapat meningkatkan produksi jagung namun dalam nilai yang sangat kecil, dan tidak mampu mencukupi kebutuhan konsumsi jagung. Pada Tabel 8 dapat diketahui bahwa dalam kurun waktu 2017-2019 terjadi defisit neraca jagung yang cukup besar dengan nilai $5-7$ juta ton/tahun.
Tabel 8 . Hasil simulasi intensifikasi

\begin{tabular}{ccccc}
\hline Tahun & Produksi (ton) & Kebutuhan (ton) & Neraca & Kesimpulan \\
\hline 2017 & 18.855 .431 & 24.295 .635 & $(5.440 .204)$ & Defisit \\
2018 & 18.444 .383 & 24.983 .347 & $(6.538 .964)$ & Defisit \\
2019 & 18.042 .295 & 25.693 .370 & $(7.651 .075)$ & Defisit \\
\hline
\end{tabular}

\section{Ektensifikasi realistis dan intensifikasi}

Dari hasil simulasi untuk skenario kebijakan ektensifikasi realistis dan intensifikasi secara bersamaan yaitu melalui PAT sebesar 1 juta Ha dan peningkatan produktivitas sebesar 53,18 di tahun 2017, maka hasil produksi yang tercapai dapat dilihat pada grafik Gambar 9 dan Tabel 9. Produksi di tahun 2017 mampu mendekati total kebutuhan atau konsumsi jagung nasional, meskipun ditahun 2018-2019 kembali terjadi defisit atau tidak terpenuhi permintaan jagung nasional. Dari Tabel 9 dapat dilihat juga nilai kekurangan produksi jagung skenario ektensifikasi realistis dan skenario intensifikasi yaitu sekitar 1-2 juta ton/tahun.

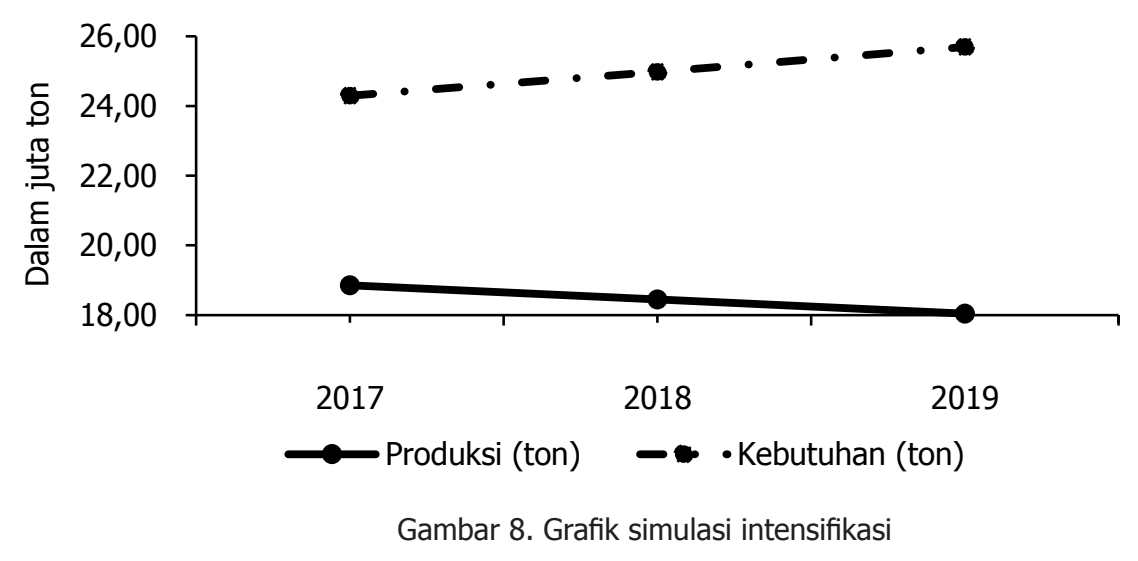




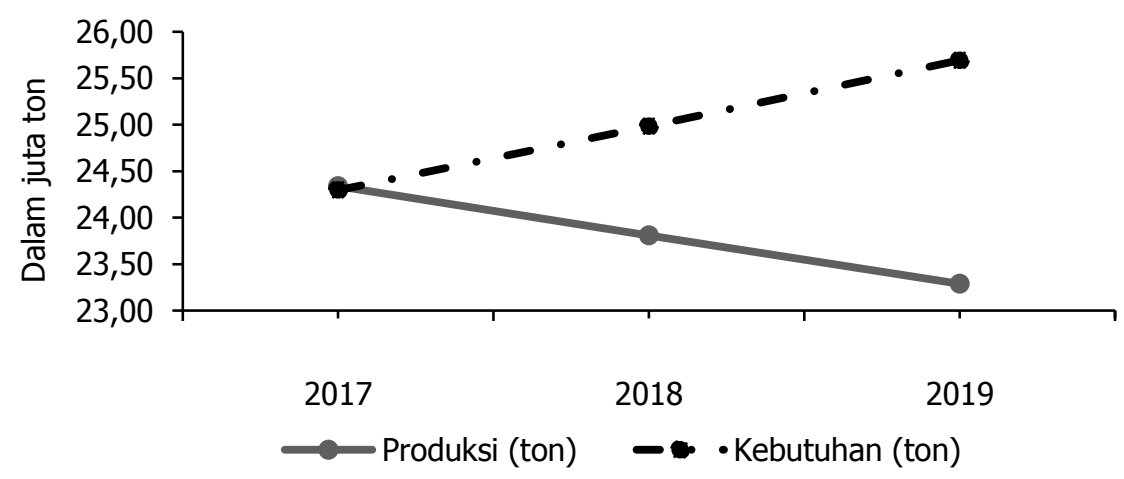

Gambar 9. Grafik simulasi ekstensifikasi dan intensifikasi

Tabel 9. Hasil simulasi ekstensifikasi dan intensifikasi

\begin{tabular}{ccccc}
\hline Tahun & Produksi (ton) & Kebutuhan (ton) & Neraca & Kesimpulan \\
\hline 2017 & 24.337 .423 & 24.295 .635 & 41.788 & Surplus \\
2018 & 23.806 .868 & 24.983 .347 & $(1.176 .479)$ & Defisit \\
2019 & 23.287 .878 & 25.693 .370 & $(2.405 .492)$ & Defisit \\
\hline
\end{tabular}

\section{Hasil Simulasi Kebijakan terhadap Tingkat Swasembada Jagung}

Dari hasil simulasi keseluruhan skenario maka dapat di lihat rangkuman persentase capaian produksi terhadap tingkat swasembada jagung adalah:

Tabel 10. Persentase capaian produksi terhadap tingkat swasembada

\begin{tabular}{cccccc}
\hline Tahun & 1 & 2 & 3 & 4 & 5 \\
\hline 2017 & 80 & 100 & 110 & 78 & 100 \\
2018 & 79 & 95 & 105 & 74 & 95 \\
2019 & 78 & 90 & 99 & 70 & 91 \\
\hline
\end{tabular}

Keterangan :

Skenario 1 : Ektensifikasi Pesimis

Skenario 2 : Ektensifikasi Realistis

Skenario 3 : Ektensifikasi Optimis

Skenario 4 : Intensifikasi

Skenario 5 : Ektensifikasi Realistis dan Intensifikasi

Pada Tabel 10 dapat diketahui bahwa, pada tahun 2017 skenario ekstensifikasi optimis; realistis; dan perpaduan skenario ekstensifikasi dan intensifikasi yang mampu memenuhi kebutuhan nasional jagung hingga 100\%. Kemudian di tahun 2018 hanya skenario ekstensifikasi saja yang mampu memenuhi 100\% kebutuhan nasional jagung. Sedangan di tahun 2019 tidak ada satu scenario yang berhasil mencapai $100 \%$ memenuhi kebutuhan jagung nasional. Skenario yang signifikan dalam mendukung swasembada jagung adalah skenario ekstensifikasi realistis; optimis dan perpaduan skenario ektensifikasi realistis dan intensifikasi. Namun jika target swasembada jagung yang diharapkan sampai dengan tahun 2019 atau berkelanjutan, maka hanya tidak ada skenario yang bisa menjadi skenario terbaik untuk mencapainya.

\section{Rekomendasi Perencanaan Kebijakan Swasembada Jagung}

Dengan melihat plotting data historis dan data simulasi tahun 2009-2015 pada Gambar 10 dan Gambar 11 dapat diketahui bahwa luas lahan tanam jagung memiliki kecenderungan atau trend menurun. Sedangkan pada produksi jagung justru berkebalikan dan cenderung mengalami peningkatan setiap tahunnya. Hal ini menjadikan indikasi dan membuktikan bahwa bukan kebijakan PAT (menambah luas lahan tanam jagung) yang sesuai untuk menggenjot produksi jagung namun kebijakan lain yaitu kebijakan intensifikasi atau peningkatan produktivitas jagung yang lebih tepat sasaran.

Peningkatan produktivitas jagung ini erat kaitannya dengan penggunaan teknologi. Adapun teknologi yang dimaksud diantaranya adalah: (1) Teknologi benih, yaitu benih yang tahan hama dan tahan kering, benih (komposit dan hibrida) unggul, dan benih yang memiliki umur genjah; (2) Teknologi pupuk, yaitu pupuk yang efisien dan tepat untuk tanah dan jagung; (3) Teknologi proses, yaitu terkait dengan pola tanam dan pengolahan pasca dan pra panen; (4) Teknologi peralatan, yaitu alat alat mekanisasi yang sesuai, tepat guna dan dapat meningkatkan rendemen serta kualitas jagung.

Sesuai dengan teori ekonomi mikro yang berlaku terkait input faktor produksi, dalam hal ini input faktor produksi lahan yang bersifat tetap dikarenakan penambahan lahan jagung untuk tiap tahunnya tidak 
dimungkinkan, sedangkan faktor produksi lain bersifat variable. Pada Gambar 12 dapat dilihat bahwa yang mampu menggeser output ketingkat yang baru adalah dengan penggunaan teknologi. Faktor produksi lahan atau X1 bersifat tetap, dengan adanya kebijakan intensifikasi (peningkatan produktivitas) maka akan menggeser kurva total produksi jagung, yang semula 10 ton akan menjadi 20 ton (asumsi).

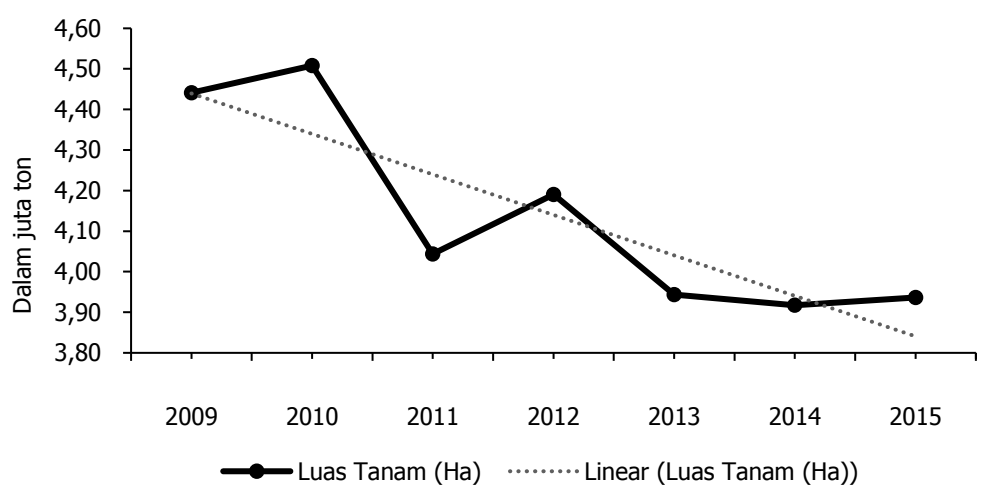

Gambar 10. Luas lahan tanam jagung $(\mathrm{Ha})$

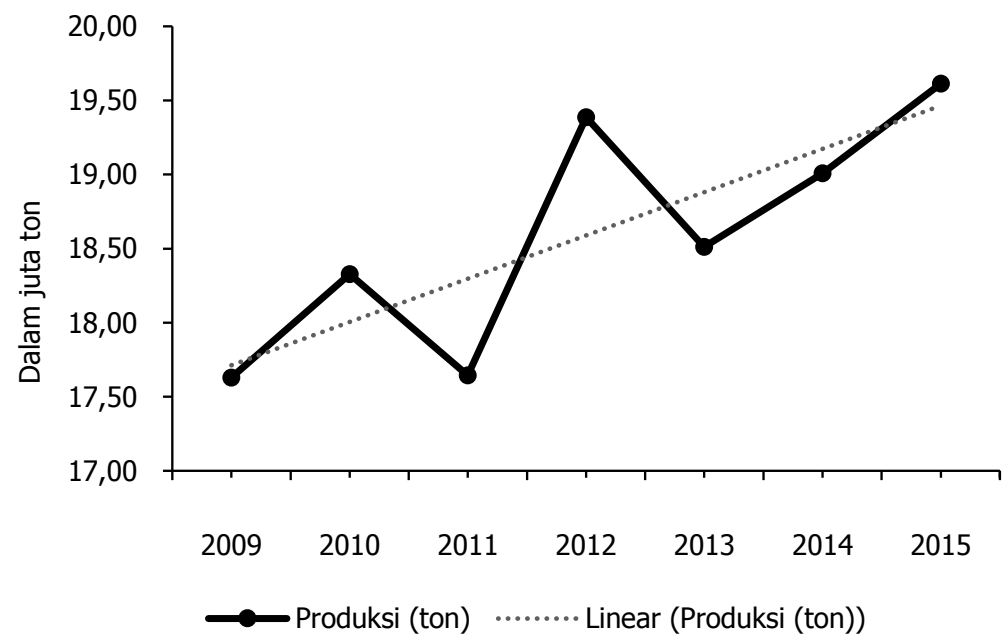

Gambar 11. Produksi jagung (ton)

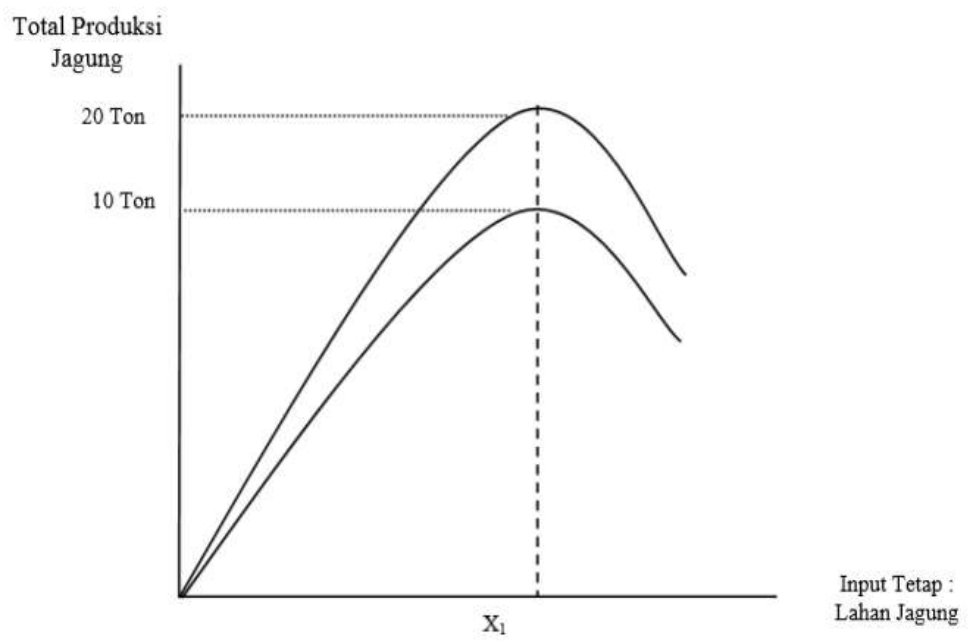

Gambar 12. Kurva pergesaran output akibat perubahan teknologi Sumber: Pindyck dan Rubinfield (2014) 


\section{KESIMPULAN DAN SARAN}

\section{Kesimpulan}

Dari penelitian dan pembahasan yang telah dilakukan dengan menggunakan simulasi sistem dinamik maka hasil skenario kebijakan ektensifikasi (pesimis, realistis, optimis); intensifikasi; dan perpaduan antara ektensifikasi realistis dan intensifikasi, masih belum mampu mendukung terwujudnya swasembada jagung secara berkelanjutan hingga akhir RPJMN 2014-2019. Sedangkan swasembada jagung jika hanya ditargetkan di tahun 2017 saja, maka kebijakan ekstensifikasi realistis (tercapai 100\%); optimis (tercapai 100\%); dan perpaduan antara ektensifikasi realistis dan intensifikasi (tercapai 100\%) yang akan mendukung swasembada jagung. Dapat ditarik kesimpulan, bahwa kebijakan yang ditetapkan oleh Kementan dalam meningkatakan produksi jagung sebagai upaya tercapainya swasembada jagung melalui PAT dan Peningkatan produktivitas kurang tepat dilakukan jika ingin mengejar target swasembada jagung hinga akhir RPJMN III di akhir tahun 2019.

\section{Saran}

Beberapa saran untuk penelitian selanjutnya adalah penelitian dilakukan dengan data sekunder dan bersifat makro, sehingga untuk lebih mendalam dapat dilakukan dengan menggunakan model yang ada namun disesuaikan dengan kondisi tiap pulau atau provinsi dan penelitian masih menggunakan beberapa asumsi dikarenakan keterbatasan akses dan waktu, sehingga untuk penelitian selanjutnya jika memungkinkan data untuk asumsi dalam model sesuai dengan kondisi sebenarnya.

\section{KONFLIK KEPENTINGAN}

Penulis menyatakan bahwa artikel ini asli hasil penelitian para penulis, hanya dipublikasikan pada jurnal ini, dan tidak ada konflik kepentingan.

\section{DAFTAR PUSTAKA}

Axella, O., \& Suryani, E. (2012). Aplikasi model sistem dinamik untuk menganalisis permintaan dan ketersediaan listrik sektor industri (Studi kasus: Jawa Timur). Jurnal Teknik ITS, 1, A339- A344. DOI: 10.12962/j23373539. v1i1.1039

Badan Pusat Statistik. Statistik Pertanian 2015. Diakses pada April 10, 2017, dari http://bps.go.id.

Badan Pusat Statistik. Produksi Jagung. Diakses pada Mei 21, 2017, dari http://bps.go.id
Badan Pusat Statistik. Statistik Indonesia 2016. Diakses pada Maret 20, 2017, dari http://bps.go.id.

Banctacut, T., Akbar, M.T., \& Firdaus, Y.R. (2015). Pengembangan jagung untuk ketahanan pangan, industri dan ekonomi. Jurnal Pangan, 24(2), 135-148. DOI: $10.33964 / j p . v 24 i 2.29$

Dharmayanti, S., Suharno, \& Rifin, A. (2013). Analisis ketersedian garam menuju pencapaian swasembada garam nasional yang berkelanjutan. Jurnal Sosial Ekonomi Kementerian Pertanian, 8(1), 81-95. DOI: 10.15578/jsekp.v8i1.1201

Falianty, T.A. (2012). Swasembada VS Impor, Komoditas pertanian strategis. Agrimedia, 17(2), 4-7.

Harmini., A, R.W., \& Atmakusuma, J. (2011). Model dinamis sistem ketersedian daging sapi nasional. Jurnal Ekonomi Pembangunan. Jurnal Ekonomi Pembangunan, (12)1,128-146. DOI: 10.23917/jep.v12i1.211

Hasan, N., Suryani, E., \& Hendrawan, R. (2015). Analysis of soybean production and demand to develop strategic policy of food self sufficiency: a system dynamics framework. Procedia Computer Science-Elsevier , 72, 605 - 612. DOI: 10.1016/j.procs.2015.12.169

Hasibuan, A.M., Nurmalina, R., \& Wahyudi, A. (2012). Policy analysis of cocoa downstream industry. Jurnal Informatika Pertanian, 21(2), 59-70.

Kementerian Perencanaan dan Pembangunan Nasonal. (2014). Buku 1 Agenda Pembangunan Nasional: Rancangan Awal Rencana Pembangunan Jangka Menengah Nasional 2015-2019. Jakarta, Indonesia : Bappenas.

Kementrian Pertanian. (2014). Rencana Strategis Kementrian Pertanian Republik Indonesia 2015-2019. Jakarta, Indonesia: Kementrian Pertanian.

Kementrian Pertanian. (2016). Direktorat Jenderal Tanaman Pangan : Petunjuk Teknis Kegiatan Jagung 2016. Jakarta, Indonesia: Kementrian Pertanian.

Kementrian Pertanian. (2016). Outlook: Komoditas Pertanian Sub Sektor Tanaman Pangan Jagung. Jakarta, Indonesia : Kementrian Pertanian.

Kementrian Pertanian. (2017). Pedoman Pelaksanaan Kegiatan Jagung. Jakarta, Indonesia : Kementrian Pertanian.

Mahbubi, A. (2013). Model dinamis supply chain beras berkelanjutan dalam upaya ketahanan pangan nasional. Jurnal Management dan Agribisnis, 10(2), 81-89.

Mahbubi, A. (2015). Sistem dinamis rantai pasok industrialisasi gula berkelanjutan di pulau madura. Jurnal Agriekonomika, 4(4), 200-211. DOI: 10.21107/ agriekonomika.v4i2.974

Mulatsih, S. (2012). Daging sapi : Swasembada atau impor?. Agrimedia 17(2), 50-58.

Pindyck, R.S., \& Rubinfield, D.L. (2014). Microeconomics (7th ed). New Jersey, USA : Prentice Hall International. 
Purwantini, T.B. (2013). MP3EI dan Swasembada Pangan Berkelanjutan. Agrimedia, 18(2), 23-30.

Sofyang, Rumana, D., \& Kaimuddin. (2012). Sistem dinamis daya dukung lahan pertanian dalam rangka swasembada beras sulawesi selatan. Diakses pada tanggal Februari $15,2016$.

http: / / pasca.unhas.ac.id/jurnal/files / f5c5d61919e4853d39b2d07070cdc9b1.pdf.

Somantri, A.S., dan Ridwan Thahir. (2007). Analisis sistem dinamik ketersediaan beras di marauke dalam rangka menuju lumbung padi bagi kawasan timur indonesia. Buletin Teknologi Pascapanen Pertanian, 3, 28-36.

Sterman, J. D. (2000). Business Dynamics: System Thinking and Modeling for a Complex World (2nd ed). Boston, USA : Irwin McGraw-Hill.

Suryana, A. (2008). Menelisik Ketahanan Pangan, Kebijakan Pangan, dan Swasembada Beras. Jurnal Inovasi Pertanian, 1(1),1-16.

Swastika, Dewa K.S. \& Manikmas, Made Oka A. \& Sayaka, Bambang \& Kariyasa, Ketut. (2005). The Status and Prospect of Feed Crops in Indonesia, Working Papers 32724, United Nations Centre for Alleviation of Poverty Through Secondary Crops' Development in Asia and the Pacific (CAPSA). https://ageconsearch.umn.edu/ record/32724/
Tastra, I, K., Ginting, E., \& Fatah, G.S.A. (2012). Menuju swasembada kedelai melalui penerapan kebijakan yang sinergis. IPTEK Tanaman Pangan, 1(1), 47-57.

Ustrina, I.N.G. (2015). Dynamic modeling of rice stock in Bali Province, Indonesia. Journal of Business and Management, 7(26),173-180.

Wibowo, A. D. (2016). Dinamika ketersediaan beras: Studi kasus di kalimantan selatan. Jurnal Ziraah, 41(2), 242249.

Yunitasari, D., Juanda, B, \& Nurmalina, R. (2015). Menuju swasembada gula nasional : Model kebijakan untuk meningkatkan produksi gula dan pendapatan petani tebu. Jurnal Ekonomi dan Kebijakan Publik, 6(1), 1-15. DOI: $10.22212 /$ jekp.v6i1.160

Zakaria, A. (2011). Kebijakan antisipatif dan strategi penggalangan petani menuju swasembada jagung nasional. Analisis Kebijakan Pertanian, 9(3), 261-274. DOI: $10.21082 / a k p . v 9 n 3.2011 .261-274$ 